\title{
Psycho-social and Spiritual Backgrounds, Experiences, and Needs as a Transsexual: A Qualitative Study within Persatuan Insaf Pahang
}

\author{
Draman $\mathrm{S}^{\mathrm{a}}$, Maliya $\mathrm{S}^{\mathrm{a}}$, Liyana $\mathrm{A}^{\mathrm{a}}$, Farhani $\mathrm{S}^{\mathrm{a}}$, Jannah $\mathrm{R}^{\mathrm{a}}$, MR Razman ${ }^{\mathrm{b}}$ \\ ${ }^{a}$ Department of Family Medicine, ${ }^{b}$ Department of Community Medicine, Kulliyyah of Medicine, International \\ Islamic University Malaysia, 25150 Indera Mahkota, Kuantan, Pahang, Malaysia
}

\section{ABSTRACT}

Introduction: Transsexuals face discriminations and rejections from the Malaysian society. The number of studies done on understanding the phenomenology, experiences, and problems faced by transsexuals is still few in Malaysia. This research aims to document their psycho-social and spiritual backgrounds and the relevant experiences, and to explore their perceptions and needs as male-to-female transsexuals in the context of Persatuan Insaf Pahang, Malaysia. Materials and Methods: A qualitative research was carried out in July and August 2015 among eight male-to-female transsexual adults in Kuantan, Pahang. Snowball sampling was used. Participants who gave consent were interviewed in two focus groups. Data obtained was transcribed and used as the primary data source. Results: Subjects in this study reported confusions over their gender identity since childhood. They struggled against conflicts regarding their transsexuality in adolescence, and eventually many quit their studies. As adults, they were discriminated against in employment and religious settings. They provided positive feedbacks on religious authorities who could understand problems unique to transsexuals and empathise with the transsexual community. Conclusion: The psycho-sexual phenomenology is the same in transsexuals all over the world. Misunderstanding and discrimination from the society remain heavy towards this community. Transsexuals should learn to adapt to meeting expectations from the society as well, so they could be accepted in public. They will need religious guidance and spiritual support for better quality of life. Dedicated efforts are still needed in training professionals in the educational, medical, and religious fields to attend to the specific needs of transsexuals in this country.

KEYWORDS: Transsexual, Islam, spirituality, discrimination, influence

\section{INTRODUCTION}

A transsexual, or a transgender, refers to an individual who experiences persistent and distressing discomfort with his or her biological sex, and wishes to live his or her life to varying degrees as the opposite sex from which he or she has been born with. ${ }^{1,2}$ Majority of transsexuals in Malaysia and other parts of the world are male-to-female transsexuals. ${ }^{1,3-6}$

Islam is the official religion in Malaysia, where the majority of the Malaysian population is the Muslims. Accordingly, most of the transsexuals in Malaysia are Muslims as well. ${ }^{2,7,8}$ The strict male/ female gender dichotomy in Islam classifies male-to-

Corresponding author:

Samsul Draman

Department of Family Medicine

Kulliyyah of Medicine

International Islamic University Malaysia

25150 Indera Mahkota

Kuantan, Pahang, Malaysia

Email: nurin@iium.edu.my

+6013-9827277 (mobile) +609-5704572 (tel)

$+609-5716542$ (fax) female transsexuals into males. ${ }^{3}$ However, because of the gender identity and expression of these transsexuals, they are often discriminated and shunned by the Malaysian society. ${ }^{2,8-10}$ Aside from facing difficulties in education, employment, and health care, these transsexuals also faced stigmatizations from Malaysian religious authorities. ${ }^{7,8}$

There have been few studies on transsexuals in Malaysia. Very few in-depth studies have attempted to describe the phenomenon and to understand the problems male-to-female transsexuals face in the Malaysian society. The purpose of this study was to document their psycho-social and spiritual backgrounds and the relevant experiences, and to explore their perceptions and needs as male-to-female transsexuals in the context of Persatuan Insaf Pahang. This paper does not serve to be conclusive of all the problems faced by all transsexuals in Malaysia.

Persatuan Insaf Pahang is a non-governmental organization based in Kuantan, Pahang, a town in Malaysia, that focuses on the special needs of male-to -female transsexuals. It was established by a Family Medicine specialist, and run by doctors and religious teachers. Its members consist of both Muslim and non 
-Muslim transsexuals from all kinds of backgrounds and age groups. The objectives of this nongovernmental organization are to educate the transsexuals on transsexual-related medical issues such as sexually transmitted diseases and hormone use, to handle their psycho-social welfares such as hospitalization and death-related services, and to provide them with spiritual teachings, counselling services, and supports.

\section{MATERIALS AND METHODS}

This was a qualitative study, where in-depth interviews were carried out on focus groups. The subjects were identified by a contact person who was a transsexual acquaintance of one of the authors. From the male-to-female transsexuals who were involved in Persatuan Insaf Pahang, eight subjects understood and were willing to participate in the study. They were all Malaysian citizens living in Kuantan, above 18 years old, and could communicate in Bahasa Malaysia.

The methodology of this study grossly followed the suggestions from Onwuegbuzie. ${ }^{11}$ The eight subjects were divided into two focus groups, and were interviewed on two separate days respectively in July and August 2015. The sessions were conducted in a private, isolated room at the Primary Care Clinic, International Islamic University Malaysia, Kuantan campus. Among the authors, three were involved in the interview sessions- as an interviewer, a scriber, and a manager of the recording systems. Their roles were the same in both sessions.

The subjects were interviewed individually within each focus group, while the other subjects were allowed to add in explanations whenever necessary. Each interview session was done in Bahasa Malaysia, and was based on seven domains: (1) brief background, (2) acceptance and coming out as a transsexual, (3) religion background, (4) family background, (5) peer influence, (6) family influence, and (7) perceptions on being a transsexual. Every subject was asked all questions, and was encouraged to provide further information for discussions. Each session lasted about one and a half hours. It was recorded with the subjects' permissions, from beginning until the end, with a video and audio camera, and also a voice recorder for backup purpose.

The recordings were then transcribed manually by the three authors involved in the interview. Relevant non-verbal communication data (e.g. body gestures, pitch and tone of voice, interpersonal space, etc.) by the subjects were included in the transcript as well. The transcript was then verified twice by the authors against the recordings, and was then used as the primary data source.

Verbatim quotes were used in this study to assist in describing the findings. They were translated into English by one of the authors, who was also an experienced translator familiar with both Malay and English linguistic cultures.

\section{RESULTS}

\section{Brief background}

The subjects all belonged to the Malay ethnicity, and were all Muslims. Their age ranged from 24 to 65 years old. They were all stable residents in Kuantan. One of them was a divorcee with five children, two adopted children, and had two grandchildren living with him; one was single and had two adopted children; the rests of the subjects were single and childless. Among the eight subjects, five received but did not complete secondary education. For the rest, one of them never received any formal education, one of them quit while studying for diploma, while another one completed diploma. Half of them were still sex workers. One of them never sold sex. The other three subjects quit the sex trade; one of them was now a make-up artist. The transsexual who never involved in the sex trade was a businessman. All subjects had female nicknames.

\section{Psycho-sexual phenomena of these transsexuals, and their psycho-social experience and problems}

The subjects began to notice a disagreement between their gender identity and anatomical sex during preschool years to early years in primary school. They strongly disliked and rejected "boyish" activities such as sports. Instead, they enjoyed playing with female friends, and preferred feminine toys and play activities. Some took part in feminine roles during school activities, such as being a dancer in feminine costumes and joining school projects that involved only girls. Since primary school, they would try on feminine dresses and put on make-ups because they "love to look beautiful". The timid ones would wear female clothing when they were alone at home, while the showy ones would cross-dress in public. According to their description, four of them never cross-dressed fulltime, three cross-dressed fulltime but wore male attire in formal occasions such as attending schools and religious events, while one subject was once a committed full time cross-dresser but now had quit because of occupational requirement. Their experiences in schools varied. Some teachers were concerned about their crossgender behaviour, some were very harsh towards them, while some were rather accepting.

"Since I was in primary one... I used to walk a very girly gait. When I saw men bathing near the well, I had this weird feeling, 'Eh? I'm a boy, why do I like men? And why do I wish to be desired by men?'”

"I used to study in a village school, I was the only 'girl' there, so whenever the school held a festival, I had to be the one on stage, yeah, I wore girly clothes, and I had to dance..." 
"In my school, during physical education classes, the boys would play football in the field, and girls would play netball. When the girls did not have enough people in their team, the teacher would tell me to join them."

"The pressure was real. In school. From my teachers. The whole school knew I was a girly boy."

When they reached adolescence, schooling became difficult. It was because these transsexual adolescents faced rejection and discrimination in schools, and were also struggling with confusion trying to comprehend their transsexuality. No proper guidance or counselling service was available for them. One of the subjects was "so lost that he had gone insane", and even had recurrent thoughts of suicide. He eventually sought help from a psychiatrist, but the treatments provided were futile. These transsexuals began seeking emotional support from elder male-to-female transsexuals in the society outside schools. Male-to-female transsexuals usually gathered in lorong at late night. Lorong is a Malay word for small alley; but to suit the context, it refers to dark and hidden places such as backstreets, and carries a negative meaning when used colloquially.

"Then our discipline teacher protested (against me). He organised a school assembly, called all the girls. And then the girls won't befriend with me anymore. They were afraid. The discipline teacher scolded me because he was concerned about me, he was worried that I would rebel and became worse. But then the whole class couldn't do school work with me anymore. I became very stressed, so I began to skip school. I desperately wanted to find my own kind of friends. Because my schoolmates won't befriend me anymore."

"I was used to getting hit by teacher in front of everyone in my school every time during weekly school assembly, that was really normal for me."

Peer support among these male-to-female transsexuals was strong. The adolescent transsexuals "finally found where they belonged" after meeting other transsexuals in lorong. Besides providing emotional comfort and company for each other, they also shared information about female hormones, breast surgery, and facial feminization procedures.

"I thought I heard from people that there was this lorong in Terengganu (a state in Malaysia) where transsexuals often go. I really wanted to go. My late cousin brought me there at night. I was in Form 3 at that time. I was really looking forward to meeting people of my own kind; I wanted to mix with them, a place where I can vent my emotions..."

"Sometimes we go to lorong to look for friends who could understand us. So it's a place for us to share love and problems."
Being friends with these transsexual peers, who often worked as sex workers, these adolescents also soon became involved in the sex trade, as early as when they were 15 years old. They usually went to schools during daytime, and came out to sell sex at night. They would wait for customers, who were all men, in lorong.

Selling sex fulfilled their basic needs. It gave them easy money, granted them sexual gratification, and made them feel desired by men. Thus, schooling and education were no longer necessary for them. They quitted without completing secondary or tertiary education.

"We become sex workers because we can have beauty, money, and our sexual desires fulfilled. And we can have friends with the same interest, and they understand us."

"Who doesn't like easy money? During those days, RM10 could buy a lot of things. How luxurious. After some time, I didn't want to go to school anymore. Three of my male teachers came to lorong to persuade me to go back to school, 'If you're a stupid student, I won't persuade you. But your academic performance is excellent. It's a big loss if we just leave you here, we will regret for letting go of a very intelligent student.' A week later, I went back to school. But in the end I left school anyways."

"My elder sister told me to continue my studies (after diploma), but I can't, because I'm already inside this (as a sex worker), I'm getting money every single day, so I can't (quit)."

"Sometimes I feel very proud of myself. How? If you compare normal people with transsexuals, I can drive cars that normal people can't afford. I have my shop. I have my own bank savings. I own a bungalow. Other normal people won't have all these. Although people always mock me, I feel strong, I am independent. I have everything."

Some of the transsexuals mentioned that, nowadays, they no longer had to wait in lorong at late night to receive customers. With the advancement in technology, they were able to advertise themselves through mobile messaging apps such as WeChat. Customers would approach these sex workers through mobile messaging, and these sex workers could provide sex service at any time of the day. Customers who previously felt uncomfortable or embarrassed with approaching sex workers in lorong could now have easier access to transsexual sex workers. In this way, the transsexual sex workers' income multiplied.

The four transsexual sex workers in this study were aware that being in the sex trade "was not a good thing". However, they were not able to get out from sex trade, because they had no sufficient skills to work, and selling sex brought them wealth enough to 
live an easy, satisfied life. A few transsexuals even went to nearby countries such as Singapore, where their sex service had been exceedingly welcomed and abundantly paid.

"We go there (Singapore) once a month. We'll bring back 20 thousand (ringgit Malaysia), sometimes 25 thousand."

Discriminations from employers and colleagues also prevented the transsexuals from getting decent jobs.

"I'm tired of all the discrimination by the employer and my colleagues at the work place. I quit the job and end up now I am a sex worker."

"We can quit our jobs in lorong. We can. Provided people let us be who we are (cross-dressers). Otherwise we'll just have to stay at lorong, wait for customers. As sex workers, we get to be who we are, and we get paid. So we are satisfied."

(A few other subjects nodded in agreement.)

"I went for a job interview in one of the public universities. They told me I could be accepted, but with one condition - I have to cut my hair short like a man. So I told them, 'Sorry I can't do that.' I refused their offer, I am more comfortable being a sex worker."

However, if the transsexuals could dress in attires accepted by the public, they could actually do very well.

“I don't feel neglected by the surrounding society. I work with the community. The society accepts me well. It is just that I have to dress properly in public, be polite with people, and now the community accepts me well."

Majority of the transsexuals in this study took female hormones, without prescriptions from practicing physicians. Their sources of female hormones were over-the-counter oral hormonal contraceptive pills. Transsexuals who took hormones would look more beautiful, and their price as sex workers could be raised to as high as RM1000 per night. Majority of the subjects started taking female hormones around the age of adolescence, as early as 15 years old, to develop the physical appearance of female. They were not given adequate information on hormone use, and thus were unaware of the safe dosages and negative effects of these hormones. Excessive consumption of hormone was common among these male-to-female transsexuals. One of the subjects developed diabetes mellitus and chronic kidney disease at the age of 18 as a result of complications of excessive hormone intake.

All subjects in this study reported total absence of heterosexual behaviour. They never experienced sexual arousal towards female, and instead were all sexually attracted to male. During adolescence, they would flirt with boys and ask them out for dates. One of the subjects married a woman because he had to conform to the social norm of having a heterosexual marriage. However, he also kept a faithful male partner for 20 years, and often sold sex at nights. With his wife, he was unable to achieve sexual arousal without fantasising the scene of having intercourse with a "handsome and masculine man". They divorced after having five children, since he felt guilty towards his wife for being unfaithful, and also because of social discriminations she faced as the wife of a sex worker. After the divorce, he remained in good terms with his ex-wife, treating her like "his own little sister" and visited her regularly.

"I used to force myself to have sex with my wife. I couldn't behave like a normal man. For example, a normal man would suckle the woman's breasts. But really I couldn't do it - it just didn't cross my mind at all. When I wanted to give my wife (sexual pleasure), I would have to force myself to fantasise a very handsome and masculine man... Yeah, I can achieve (sexual) pleasure only when I am with a good looking man."

"People who have souls like ours have no feelings towards women."

Among the subjects, two underwent breast and facial feminization surgeries, but none had done sex reassignment surgery.

The two older subjects (above 40 years old) in this study mentioned that, as they aged, their female physical appearance would not be as appealing to men as the younger transsexuals. They eventually stopped cross-dressing and selling sex since they no longer attracted customers. To make a living, one of them helped out in a food stall, while the other transsexual leased one of his houses. Their sexual desire for men persisted, although not as strong as when they were younger.

"Our age is another factor. We feel embarrassed to wear (revealing female attires)."

"Although I'm already old, my desire towards men still exists. Now l'd be like, 'Wow look at that man selling fried bananas, he is so handsome... Just look at him, oh dear... I'll surely come again next time.' If I'm still young, I'll seduce him for sure!'

"We are men, so it's like, our desire never dies. Unlike women, once their desires have gone, it's gone for good. I'm telling you this because I've experienced it. I'm honest."

All of the subjects claimed that they "had been born with the nature of women" and disagreed with the idea that they could become straight males. They have no intention of getting married or having children of their own. 
"This is impossible. If people force us to become straight men, we will rebel. We can try wearing men's clothing though. But if you expect us to be pure straight men, that will be really difficult."

“Transsexuals are us, we don't hide our female identity. Transsexuality refers to our nature, it's our womanly instinct. How a woman feels, that's how we feel. We are not gays, who appear as men; or bisexuals, who attract both men and women."

"I even offered special prayers so God would change me into a woman."

"I have repented so many times already. I'm always like, “God, I really don't want to be like this (transsexual). I really don't want it.' But I really don't know how to change myself. Nobody could guide us."

\section{Families' attitude and influence}

Of the eight subjects in this study, six came from stable and happy families. Of the other two subjects, one was an orphan raised up by his relatives, another subjects' parents were divorced.

All subjects had relatives, both distant and close, who belonged under the LGBTQ (lesbian, gay, bisexual, transsexual, and queer) spectrum. They disagreed with the idea that their sexual identity and sexual orientation were influenced by these relatives. To them, transsexuality was something they were born with, and were definitely not influenced by others.

"I've been teaching my children not to be like me (as a transsexual). They didn't want to become like me as well. But in the end, they became transsexuals anyways."

"My mom always, always wanted daughters. My family could see my potential (to become a girl) since I was very small... I was brought up as a girl to keep my elder sister company... And then my little brother was born. He went through the same thing I did. But he isn't like this (transsexual) at all. Not even a little bit. So this (transsexuality) is my instinct."

Generally, families of these subjects were accepting towards their sexual identity. A few families displayed denial during the subjects' childhood and adolescence, but accepted them eventually. The subjects were in good terms with their family members. Since most of the transsexuals in this study were single and had no dependent, they were helpful with house chores when they returned to their families, and single-handedly carried the responsibility of looking after their ill family members. They were closer to their female family members than to the males, since the female family members accepted them more easily. With their female family members, they were able to openly discuss topics that relate to women, such as menses, gynaecological diseases, and their female relatives' romantic relationship.

\section{Religious background and influence}

Among the eight subjects, four grew up in a religious environment. During childhood, they were taught the obligations as a Muslim and rules in reciting the Holy Quran. They were familiar with the etiquettes in prayers for Muslim males. In terms of carrying out religious duties, all of them identified themselves as males.

"I wear male attire (when praying)... Even though we now have big breasts, have done surgeries all over the body, we are still aware of what (gender) we are in origin.

"Those two (adopted daughters) cannot live with me, because I am a man (in religious context)."

"(During congregational prayers) people would call us to pray together with them (men). I feel so happy... During Friday prayers, people (men) would greet us first, it makes us feel not isolated from the society."

These four transsexuals described that mixing with transsexual peers from lorong had lead them astray from practising their religion. When they wanted to approach an ustaz (a Malay word for male religious teacher) for inquiries on religious matters, they would be looked down upon, and rejected. Before the establishment of Persatuan Insaf Pahang, the transsexuals in this study rarely encountered ustaz who would empathise with transsexuals. Thus their confusions towards Islam were unanswered. Eventually, these transsexuals gave up practising their religion. They abandoned daily prayers, which were a compulsory religious duty for all Muslims, and other obligations in Islam.

"I was a decent child. But once I got involved with these social things, I learned about alcohol... every evil thing in this world, we know about them all."

“People like us, we don't mind learning about our religion. We will join classes for Quran recitations. But when people look at us with stigma, we will all feel down. When we meet an ustaz that are tolerant with us, we'll be like, "Alright let's go, learn from that ustaz.' We can go. This (transsexuality) is the way we are. Just don't stigmatise us. Don't judge us."

"We can force ourselves to pray. But don't force ourselves to change, because we just can't."

These transsexuals believed that having a strong faith in religion could play an essential role in their life. This was because transsexuals faced discriminations and pressures from the society, and thus had very sensitive emotions. Without having 
faith towards God, they could become easily depressed. Some subjects even reported strong suicidal intentions. Remembering God and practising religious duties such as prayers made them feel much more peaceful.

"We like this (religion). We are also seeking peace for our hearts. Us transsexuals have very unstable emotions, you know. With those effects from hormones... People don't know, deep in our hearts, we really wish for death."

"Umm, for instance, we became emotional after taking hormones. We want to cry, we want to commit suicide. All the time. So we talk to our (transsexual) friends. Our friends be like, "Have you forgotten our God? Try reciting some prayers.' So we'll remember God... Sometimes we feel possessed, so we will read Ayat Kursi (Ayat Kursi is one of the prayers recited for divine protection and to increase in one's faith)... Whatever we do, we refer to God (His religion)... We are Muslims after all."

"That's why, some of us follow (Islamic) programs. Because we know when we are with these religious people, our hearts become peaceful. The more we go, the more we want to go."

The subjects were very keen to increase themselves in faith and religious knowledge. Sometimes, these transsexuals also acquired religious knowledge from media such as the internet or television programmes. They hoped that there would be more ustaz who would empathise with the transsexuals, instead of discriminating them, to guide them when they had inquiries. They needed ustaz who were specifically trained in facing situations unique to male-to-female transsexuals.

"We are ignorant with our religion because we don't learn in depth. For those of us who have been to school, there are so many more things we want to know."

"Sometimes we just Google-search when we have problems in religion. We seek Islam because we know who we are. Our faith is still here. It really, really exists."

Common religious inquiries from these transsexuals included rulings and methods regarding prayers, financial management and child adoption according to Islamic rulings, ritual cleansing the dead body of an HIV-infected transsexual, spiritual counselling and guidance for transsexuals with clinical depression and suicidal intentions.

The transsexuals in this study recommended the authorities to provide more interesting and interactive religious programs for them.

"When the ustaz goes on and on lecturing "blah blah blah' taking forever and ever, we cannot take that.
When we sit with (more religious) transsexuals, we hear them talk about God, we feel sad, when our transsexual friends pass away, we have to think about what we should do next, follow the steps in our religion rulings..."

"You can organise contests. Transsexuals love competition. For example, you can make us memorise Quranic verses. And then give us presents. Maybe a crown. Whoever that gets to have that crown, it's like, a big wow thing. You can gather all of us. We don't mind what kind of present it is. The important thing is, somebody has to be the Number One. That number is something. That's why, if you make programs like these (lectures and talks), for three days, it's downright boring for us. Nothing goes into our head. You can just give us small gifts. We are more concerned about who gets the throne."

\section{DISCUSSION AND RECOMMENDATION}

The socio-demographic findings in this study share a roughly similar pattern with the results of other studies done in Malaysia. The subjects in this study were Malays, and were Muslims. Most of them received secondary education, while two received tertiary education. More than half of the subjects in this study involved in the sex trade, although three quit. $^{2,7-9}$

The subjects in this study were clear about the idea of transsexualism, i.e. they "had been born with the nature of women" and had "womanly instinct" while they were aware of conflicts between their anatomical sex and their gender identity. Their childhood psychosexual experience was also similar to that of the male-to-female transsexuals from other studies. They experienced confusion of their sexual identity and cross-dressed since childhood; they enjoyed feminine play activities and generally avoided boyish play activities. During adolescence and adulthood, they also attempted to change their physical appearance to resemble as closely as that of a female by taking female hormones and undergoing surgeries. Having a feminine name is universal among male-to-female transsexuals. ${ }^{7,8,12-14}$

Total absence of sexual attraction and arousal towards women in this study was consistent with previous reports; universally, the transsexuals found males to be sexually appealing instead. ${ }^{9,15}$ Identical to previous descriptions, sexual fantasies of having intercourse with a male partner were also necessary for a husband-and-wife sexual relationship, as mentioned in a previous study. ${ }^{15}$

Majority of the subjects came from happy families, were close to their family members, and had family members or relatives who belonged under the LGBTQ spectrum. ${ }^{7}$ Family acceptance towards transsexuality varies in Asian countries $^{16}$, even in Malaysia. ${ }^{9}$ But similar to the findings in this study, Malaysian transsexuals tend to be accepted more readily by family members. They were also closer to female 
family members in comparison to the males. Just like other transsexuals in Malaysia and also worldwide, the subjects in this study believed that transsexuality was something natural, not a result of being influenced by childhood environment. ${ }^{7-9}$

The transsexuals in this study still faced discriminations in the society. Based on the findings in this study, hostility from the society came from three aspects: schooling environment, work places, and religious authorities. In this paper, discussions and suggestions from the authors will be elaborated from these three angles.

\section{Schooling environment}

To begin with, transsexuals began to face obvious struggles and difficulties during adolescence, where they spent most of their times in schools. ${ }^{14}$ Findings from this study, together with previous reports, suggested that adolescence for transsexuals is a crucial and vulnerable phase of their psycho-social development. ${ }^{14,17}$ If the issues that arise during this phase are not addressed properly, significant negative impacts can occur during adulthood. ${ }^{18}$

Just like transsexuals in other parts of the world, transsexuals in this study faced worsening internal conflicts or confusion over their sexual identity. ${ }^{14,17}$,

${ }^{19}$ It is rather common that teachers and school authorities were lacking in understanding and empathy towards the unique problems faced by transsexual students. ${ }^{20}$ The transsexual adolescents needed proper channels to address these conflicts and confusions. ${ }^{17}$ Evidence shows that such confused adolescents will seek role models who behave similarly to them, and imitate what these transsexuals do. ${ }^{14}$

As seen in this study, the subjects reached out to seek peer support from other transsexuals outside school. They reported a general trend - because no proper guidance was available for them to help them face the struggles, and school environment had been harsh for them, they ended up seeking comforts from other transsexuals in lorong and then became sex workers. The influence from their transsexual peers basically determined the future of these subjects. Thus, understanding and support directed specifically to meet the needs of transsexual adolescents play a vital role in the transsexual community.

The aim of school authorities and staffs in helping transsexual adolescents should focus on deescalating conflicts and clarifying confusions in these young transsexuals, providing them with proper guidance on the do's and don'ts in relation to common problems faced by transsexuals, encourage them to develop skills that could facilitate them in employment, and encouraging them to complete formal educations. Therefore, teachers and other school authorities must be educated and trained to help transsexual students professionally. When the schools face any difficulty, they should at least be able to refer these students to agencies or organizations that could provide proper assistance.

\section{Work places}

Prostitution has been significantly associated with low levels of education, homelessness, drug use and a perceived lack of social support. ${ }^{21}$ It is not accepted as a formal, decent job in the Malaysian setting. Carnal (penile-anal or penile-oral) intercourse is a common practise between male-to-female transsexuals and their male partners, ${ }^{1,15,22}$ and is considered a punishable offence in Malaysia. ${ }^{23}$ The likelihood of spreading HIV infections also rendered the sex trade as a crime in this country. ${ }^{24}$ In addition, the legal age for consented sex in Malaysia is 16 years of age, ${ }^{25}$ However, subjects in this study involved themselves in selling sex to men earlier than the legal age. Sex trade must be ceased at all costs in this country. A transsexual chooses to engage in selling sex often because he faces social exclusion, economic vulnerability, and difficulty in finding employment. ${ }^{26}$ Efforts must be made to encourage transsexuals for proper employments.

Firstly, transsexuals must be trained to have skills to ensure that they are employable (hence, completion of secondary education would, again, be a strongly reasonable emphasis). Secondly, since it is difficult for transsexuals to accept jobs that are strict in terms of dress codes, transsexuals must be explained thoroughly that, for them to be accepted among the general public, their attitude towards dress codes on jobs must be tailored to suit public acceptance. ${ }^{27}$

This is because, being a country where practising Muslims occupy the majority of the population, it is still rather unreasonably ambitious for the entire Malaysian community to accept cross-dressing openly. In this study, the transsexuals were treated respectfully by the general public when they showed attempts in dressing up according to their anatomical sex. This suggests that discriminations could be reduced and neutralised only when both the general public and the transsexuals become willing to tolerate and accept each other, not just onesided anticipations from the transsexuals alone.

Moreover, studies in Malaysia reported that low income was common among male-to-female transsexuals in Malaysia. ${ }^{2,7,8}$ Agencies and organizations that look after the welfare of the transsexual community should also build up reserve fund so that financial support can be provided for transsexuals who have quitted the sex trade, so as to aid these transsexuals to start earning a living on their own.

\section{Religious authorities}

It has been reported that transsexuals generally harbour a negative attitude towards Islamic religion because of its strict rulings against cross-dressing and sex reassignment surgery. Religious authorities in Malaysia often showed 
discrimination and rejection towards transsexuals because they lacked understanding and empathy towards this group of people..$^{7-9}$ These factors rendered the transsexual community to be confused of the true value of embracing their religion and spirituality. Transsexuals in this study gave positive feedbacks in relation to religious authorities who were emphatic and nondiscriminating towards this community. They revealed the eagerness to embrace religion freely just like other people. Religious authorities in Malaysia must thus be reminded so as not to downgrade the transsexual communityor to treat them with injustice. Despite the negative impressions the religious authorities bear towards this community, it is never the essence of Islamic teaching to disregard anyone that comes forward to seek help. As Prophet Muhammad (peace be upon him) has always taught the Muslims:

"..... Whoever wishes to be delivered from the fire and enter the garden should die with faith in Allah and the Last Day and should treat the people as he wishes to be treated by them..."28

" Do not be envious of one another; do not artificially inflate prices against one another; do not hate one another; do not shun one another; and do not undercut one another in business transactions; and be as fellow-brothers and servants of Allah. A Muslim is the brother of a Muslim. He neither oppresses him nor humiliates him nor looks down upon him. Piety is here - and he pointed to his chest three times. It is evil enough for a Muslim to hold his brother Muslim in contempt. All things of a Muslim are inviolable for another Muslim: his blood, his property and his honour."29

Unlike the general impression given by various reports which illustrated how religion oppresses the transsexual community, ${ }^{7-9}$ findings in this study showed that dedicated religious professionals who were adequately trained in understanding the needs of male-to-female transsexuals could actually effectively assist the transsexuals towards having a better quality of life.

Inculcating spirituality when counselling these transsexuals could help them in easing their emotional stress. Teaching them prayers and Quran recitations could make them feel they could practise religion just like anyone else in the Malaysian society, where majority of the population consists of practising Muslims. Providing religious guidance in terms of Islamic rulings could clarify their misunderstandings towards religion, and thus make these transsexuals feel accepted by people of their own religion. This study has extrapolated that a number of transsexuals do grow up in families just like other normal people in Malaysia, so it would a form of injustice if they are not allowed to be involved in religious matters like other normal people do in Malaysia.
Religious authorities can also facilitate in providing suitable venues, such as mosques and halls, and organising more activities for transsexuals to gather frequently, so they could involve themselves more in environments that instil positive values of life. This way, the transsexuals would bring themselves closer to the Muslim community, and would not feel that they are being left out or neglected by the general public.

It has to be reminded that perseverance and dedication are essential qualities in providing religious support to this community. Religious issues faced by transsexuals must be studied in depth by relevant authorities to provide well-established, up-to-date guidelines in helping the transsexuals. Transsexuals are emotionally sensitive, thus, patience, empathy, and wholehearted attention are a must in taking care of the needs of these people.

Besides having trained personnel to assist these transsexuals, the mass media can be useful in facilitating transsexuals' needs in transsexual-related issues as well. Websites and mobile apps can be developed, upgraded, and tailored into transsexual-friendly tools to provide useful, up-todate information for this community, especially those transsexuals that shy away from interacting with the general public. More television programmes can be made to provide information for transsexuals, to educate the general public about transsexualism, so as to encourage tolerance and acceptance of the general public towards transsexuals, while toning down the negative image of the general public towards them.

The authors in this research would like to raise a few issues to draw the attentions of respective authorities that usually handle transsexual-related matters.

First, efforts must be made to provide holistic medical services towards the transsexual community. Taking female hormone can bring detrimental effects to these transsexuals. ${ }^{30,31}$ HIV infection is still an epidemic in this country, and sex workers are considered one of the high risk populations. ${ }^{32}$ Education on female hormone use and safe sex practice still need to be strengthened in this community. But it has to be kept in mind that these interventions serve only for the purpose of harmreduction, instead of urging the transsexuals to expose themselves to unnecessary negative effects from the hormones, or encourage them to engage more in sex trade.

Transsexuals face a lot of pressures from the society. ${ }^{9,17,18}$ They are vulnerable to having depression and possibility of suicide. ${ }^{1,7,17}$ Mental health concerns should be screened stringently in the transsexual community, so that early referral and counselling can be made. 
Secondly, authorities concerned with transsexual outreach programs should be aware of the increasing trend of customers hiring transsexual sex workers through mobile messaging apps. Instead of reaching transsexual sex workers in the traditional outreach points, ${ }^{33}$ new strategies must be invented and refined to provide interventions for transsexual sex workers who no longer appear in their usual places like lorong.

\section{Limitation}

The findings from this study were only obtained from transsexuals who gave consent to participate, involving only transsexuals from the Malay ethnicity, who were all Muslims. Besides, the sample size of this study was small. More researches with larger samples are needed to discover a broader phenomenology from the male-to-female transsexual community.

\section{CONCLUSION}

In this study within the Persatuan Insaf Pahang context, the eight male-to-female transsexual subjects were all Malay adults and Muslims. Most of them received secondary education. Majority of them had been sex workers, although three eventually quit. The psycho-sexual phenomenology in these subjects was roughly similar to male-tofemale transsexuals from other places in Malaysia and other parts of the world. Social and environmental factors alone were not able to explain the psycho-sexual phenomenology of these transsexuals. More researches fuelled by innovative thinking would be needed to discover and explain the transsexual phenomena.

Misunderstandings and discriminations from the society remained heavy towards this community. Since childhood, they faced internal conflicts because of transsexuality; while advancing into adulthood, they also experienced external struggles in terms of education, peers, employment, and religious guidance. Aside from educating the community to understand and tolerate these transsexuals to reduce discriminations, transsexuals should also learn to adapt to meet the expectations from the Malaysian society as well, particularly in terms of dress code, so they could be accepted in public. Dedicated efforts are still needed in training professionals in the educational, medical, and religious fields to attend to the specific needs of transsexuals in this country. Religious guidance and spiritual support are essential in helping the transsexuals towards achieving better quality of life. Development of strategies in helping the transsexuals must be creative and up-to-date to encourage more transsexuals to come forth to seek assistance.

\section{Conflict of Interest}

Non declared

\section{Acknowledgements}

Immense gratitude is to be expressed to International Islamic University Malaysia for providing the resources for this study, and to IIUM Ethics Committee for approving the research protocol of this study.

\section{REFERENCES}

1. Clements-Nolle K, Marx R, Guzman R, Katz M. HIV prevalence, risk behaviors, health care use, and mental health status of transgender persons: Implications for public health intervention. Am J Public Health 2001;91:915.

2. Koon Teh Y. HIV-related needs for safety among male-to-female transsexuals (mak nyah) in Malaysia. SAHARA J 2008;5:178-85.

3. Yusof K, Law W, Wong Y. Islam sebagai ad-din. 1987.

4. Bakker A, Kesteren Pv, Gooren LJ, Bezemer P. The prevalence of transsexualism in the Netherlands. Acta Psychiatr Scand 1993;87:237-8.

5. De Cuypere G, Van Hemelrijck M, Michel A, et al. Prevalence and demography of transsexualism in Belgium. Eur Psychiatry 2007;22:137-41.

6. Wilson P, Sharp C, Carr S. The prevalence of gender dysphoria in Scotland: a primary care study. Br J of Gen Pract 1999;49:991-2.

7. Teh YK. Mak nyahs (male transsexuals) in Malaysia: The influence of culture and religion on their identity. Int J Transgend 2001;5:97-03.

8. Wei CL, Baharuddin A, Abdullah R, Abdullah Z, Em KPC. Transgenderism in Malaysia. Journal of Dharma-Dharmaram Journal of Religions and Philosophies 2012;1:79-96.

9. Teh YK. Understanding the problems of mak nyahs (male transsexuals) in Malaysia. South East Asia Research 1998:165-80.

10. Goh JN. Mary and the Mak Nyahs: Queer Theological Imaginings of Malaysian Male-toFemale Transsexuals. Theology \& Sexuality 2012;18:215-33.

11. Onwuegbuzie AJ, Dickinson WB, Leech NL, Zoran AG. A qualitative framework for collecting and analyzing data in focus group research. Int J Qual Methods 2009;8:1-21.

12. Leavitt F, Berger JC. Clinical patterns among male transsexual candidates with erotic interest in males. Arch Sex Behav 1990;19:491-505.

13. Ngalob Q, Tamban C, Barrera J, et al. The Transformation of Transsexual Individuals. Journal of the ASEAN Federation of Endocrine Societies 2014;28:151.

14. Haslee Sharil Lim Abdullah LPL, Salmi Jalina Jalil. Antara Dua Dunia: Memahami Pengalaman Hidup Transeksual 2014.

15. Benjamin $H$. The transsexual phenomenon. Electronic Edition. Dusseldorf: Symposium Publishing Retrieved August 1999.

16. Winter S. Lost in transition: transpeople, transprejudice and pathology in Asia. The International Journal of Human Rights 2009;13:365-90.

17. Coleman E, Bockting $W$, Botzer $M$, et al. Standards of care for the health of transsexual, 
transgender, and gender-nonconforming people, version 7. Int J Transgenderism 2012;13:165-232.

18. Joint United Nations Programme on HIV/AIDS (UNIAIDS). The Gap Report. Geneva UNAIDS 2014.

19. Liberation T. Beyond Pink-or-Blue. Boston: Beacon Press 1998.

20. McKinney JS. On the margins: A study of the experiences of transgender college students. Journal of Gay \& Lesbian Issues in Education 2005;3:63-76.

21. Wilson EC, Garofalo R, Harris RD, et al. Transgender female youth and sex work: HIV risk and a comparison of life factors related to engagement in sex work. AIDS Behav 2009;13:902-13.

22. Garofalo R, Deleon J, Osmer E, Doll M, Harper GW. Overlooked, misunderstood and at-risk: Exploring the lives and HIV risk of ethnic minority male-to-female transgender youth. J Adolesc Health 2006;38:230-6.

23. Penal Code (Act 574). Sect. 377A. (1997 August 7.).

24. Godwin J. Sex Work and the Law in Asia and the Pacific: Laws, HIV, and human rights in the context of sex work. Thailand: United Nations Development Programme 2012. 226p.

25. Review and Consultation on the Policy and Legal Environments Related to HIV Services in Malaysia. Kuala Lumpur, UN: United Nations Country Team, Malaysia 2014. 56p.

26. Van Devanter N, Duncan A, Raveis VH, et al. Continued sexual risk behaviour in African American and Latino male-to-female transgender adolescents living with HIV/AIDS: a case study. J AIDS Clin Res 2011.

27. Irsyad A. I Was A "Mak Nyah" And Rehab Made Me See How Far I Have Strayed Away From My Religion. Malaysian Digest. 3rd November, 2015.

28. Hadith: Sahih Muslim. Book 020. Number 4546.

29. The Forty Hadith of Imam Nawawi. Hadith 35. [Sahih Muslim].

30. Moore E, Wisniewski A, Dobs A. Endocrine treatment of transsexual people: a review of treatment regimens, outcomes, and adverse effects. J Clin Endocrinol Metab 2003;88:346773.

31. Gooren LJ, Giltay EJ, Bunck MC. Long-term treatment of transsexuals with cross-sex hormones: extensive personal experience. J Clin Endocrinol Metab 2008;93:19-25.

32. The Global AIDS Response Progress Report 2014, Malaysia. Ministry of Health Malaysia 2014. Report No.

33. Malaysia National Strategic Plan on HIV and AIDS, 2011-2015. Malaysian Ministry of Health 2011. 